\title{
わが国の宇宙開発と衛星通信
}

演題はなるべく多くの方々に関心のありそうな ものとして選ばれたものであります。即ち宇宙開 発は先端技術として毎年わが国が 1,000 億円以上 の予算を費している大型プロジェクトであります し, また衛星中継を含めての衛星通信, 直接衛星 放送, あるいは気象衛星情報などは最近, われわ れの日常生活とは切り離せないほど身近なものに なっているからであります。今回は時間の関係上 これらの中で注目さるべき問題点をとり上げて申 し述べました。

そしてさらに詳しく勉強される方々のために次 の出版物を参考資料として紹介いたしました。

（一般概要紹介書）：スペースサイエンス

広済堂産報出版，2，０００月

(専門技術解説書) : 衛星通信技術

電子通信学会出版，3，500 円

また参会者に常識的な理解をしていただけるよ うK D D の企画になる次の 2 本のフイルムを映写 いたしました。

「衛星通信」: (固定衛星通信の説明)

「空と海の間に」:(海事衛星通信の説明) 以下は当日の講演の要旨であります。

\section{1. 宇宙開発とは}

宇宙開発なる用語は外来語の翻訳ではなく初期 のころ日本において創造された言葉であります。 これは(1)宇宙の探究, (2)宇宙の利用, (3)宇宙旅行, など広い範囲の探究と利用の分野を含めた意味で 使われていました。“宇宙開発”なる言葉は今で は法律用語になっておりますが, それは人工衛星

※ 国際通信施設社長, 元KDD副社長

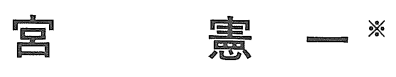

およびロケットの開発と研究を意味し, 宇宙探求 を含む広い意味では "宇宙の開発”なる用語が用 いられています。

ところで世界の宇宙研究活動は全く目覚しく, 宇宙に打ち上げられた飛行体 (人工衛星) の数も 1982年末現在においてソ連だけでも2,069 個 (内, 現在, 作動中のもの 102 個 ), 一方米国は 997 個 ( 183 個),その他の国（欧州, 日本, 中国, 印度, 豪州など）59個（ 7 個）に達しております。

日本の宇宙開発は宇宙開発委員会 (科学技術庁) がその基本政策大綱および年度計画を固めます。 またその実行は宇宙開発事業団, 宇宙科学研究所, その他, 多くの研究機関において推進されており ます。

\section{2. 宇宙の利用}

われわれの日常生活に関連のある宇宙の利用分 野は実に多様であります。それら個々のお話は省 略し，ここではその全容が分かるように伝搬対象 を, 情報, エネルギー, 物体に分類して見ますと 表 1 のようになります。

表 1 宇宙の利用

\begin{tabular}{|c|c|c|}
\hline 伝搬対象 & 利用衛星 & 利 \\
\hline \multirow{2}{*}{$\begin{array}{l}\text { 情 報 } \\
\text { (伝達) }\end{array}$} & 静 止 & $\begin{array}{l}\text { 固定衛星通信 (衛星中継)，移動 } \\
\text { 衛星通信, 直接衛星放送, 気象観 } \\
\text { 測。データ衛星中継 (TDRSS (TDRS) }\end{array}$ \\
\hline & 移＼cjkstart動 & $\begin{array}{l}\text { 資源探査, 地球 (地表) 観測, 航 } \\
\text { 海, 測地, 天体観測, 宇宙研究 }\end{array}$ \\
\hline $\begin{array}{l}\text { エネルギー } \\
\text { (伝送) }\end{array}$ & 静 止 & $\begin{array}{l}\text { 太陽光による宇宙発電と地表への } \\
\text { 電力伝送 }\end{array}$ \\
\hline $\begin{array}{l}\text { 物 体 } \\
\text { （運搬） }\end{array}$ & S T S など & 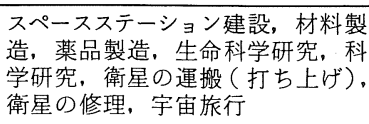 \\
\hline
\end{tabular}


今回はその中の衛星通信についてのみ。その主 要点を述べることにいたします。

\section{3. 衛星打ち上げロケット}

人工衛星の打ち上げ用ロケットは，その一部は 地上（海上）に落下し。一部は大気中に摩擦熱に より消滅するので使い捨て型ロケットとも呼ばれ ます。その代表的な各国の静止衛星打ち上げ用口 ケットを示せば表 2 の通りであります。

日本の放送衛星 ( B S - 2 ), 通信衛星 ( C S -2 )，インテルサット V 号系衛星 (写真 1参照) にアトラスセントールとアリアン 1 が使われました。

これに対し米国で開発したスペースシャトルは 地上と宇宙との間を 100 回程度も往復できる有人 のロケットで，スペース・トランスポーテイショ ン・システム（ S T S ）とも呼ばれます。 S T S は使い捨て型よりも経済性があり，万能な打上機 になると言われていましたが，実際には衛星の打 ち上げ費用が，打ち上げ料金の 2 倍以上もかかる ことがわかって，今では問題となっています。そ れは現在，世界の衛星打ち上げに対し，米国と欧 州グループ（ E S A ）との間で激しい受注競争が 展開されており，打ち上げ料金はどうしても政策

表 2 各国の衛星打ち上げロケット

\begin{tabular}{|c|c|c|c|}
\hline \multirow{2}{*}{ 国名, 機関 } & \multicolumn{3}{|c|}{ 静止衛星の重量とロケット（完成年） } \\
\cline { 2 - 4 } & $350 \mathrm{~kg}$ 級 & 1 ton級 & 2 ton級 \\
\hline 米 国 & デルタ & $\begin{array}{c}\text { アトラス・ } \\
\text { セントール }\end{array}$ & タイタン \\
\hline $\begin{array}{c}\text { 欧 州 } \\
(\mathrm{ESA})\end{array}$ & & アリアン・I & $\begin{array}{c}\text { アリアン } \\
(1986)\end{array}$ \\
\hline 日 本 & $\mathrm{N}-\mathrm{II}$ & $\mathrm{H}-\mathrm{I}(1986)$ & $\mathrm{H}-\mathbb{I}(1991)$ \\
\hline ソ 連 & & ソユーズ & ゾンダ \\
\hline
\end{tabular}

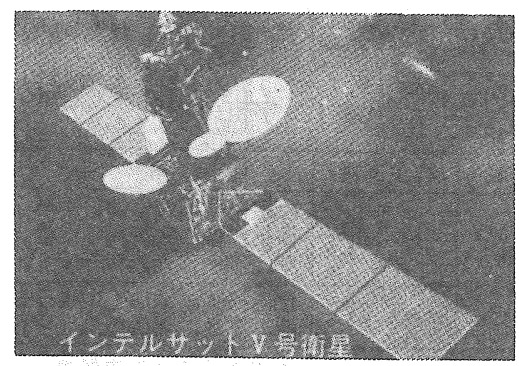

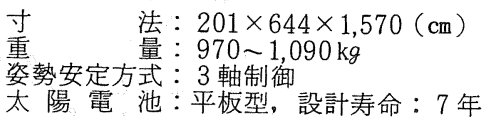

写真1 インテルサットV号系衛星
的に低く定められているからであります。したが って将来とも普通の衛星の打ち上げには使い捨て 型ロケットがなお有効ということになりそうであ ります。

しかし S T S は有人であるだけに有人でなけれ ば出来ないような目的，例えばスペースステーシ ヨンの建設などには是非とも必要なものであります。

\section{4. 日本のHーII ロケット計画}

このような状勢の下で日本は最近, 静止衛星軌 道上に重量 2 トンの衛星を打ち上げる能力をもつ HーII ロケットを1991年を目標に開発すること を決定しました。2トン衛星といえば現在，世界 で最も大型の商用通信衛星であるインテルサット VI 号系衛星にも相当します。

本年 7 月 (本講演の直後), 科学技術庁の発表 したところによれば， H - II は液体酸素と液体水 素を燃料とするエンジンを用い，補助として固体 ロケットブースター（ S R B ）付きの高能率 2 段 式ロケットであります。その構成と性能諸元は表 3 に示す通りで, 開発には 2,000 億円以上も必要 とします。なお射場は種子島であります。ところ で，それが完成した暁には日本は商用衛星の打ち

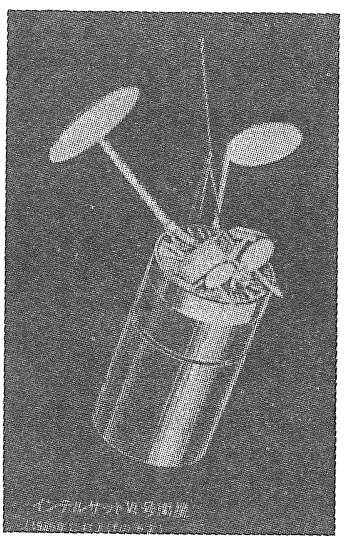

寸法：

$360 \mathrm{~cm} \varnothing \times 1,180 \mathrm{~cm}$ 重量:

$1,777 \mathrm{~kg}$

姿勢安定方式：

ジュアルスピン

太陽電池：

円筒型, 設計寿命

: 10年

写真 2 インテル サットV I 号系 衛星

表 3 H - II ロケットの主な諸元

\begin{tabular}{|c|c|c|c|}
\hline 寸法, 重量 & \multicolumn{3}{|c|}{ 全長: $46 \mathrm{~m}$, 直径: $4 \mathrm{~m}$, 全重量 : 240 トン } \\
\hline & 第 1 段 & $\mathrm{SRB}(2$ 本 $)$ & 第 2 段 \\
\hline 推 進 薬 & 液酸 / 液水 & 固体推進薬 & 液酸 / 液水 \\
\hline 推力(トン) & 95 (海上) & 260 (海上) & 10.5(真空中) \\
\hline 燃焼時間(尖) & 300 & 90 & 550 (再着火) \\
\hline 全重量(トン) & 90 & 120 & 16 \\
\hline
\end{tabular}


上げ分野では米，欧，ソと比較して小規模であり ましたが， H - II は将来の宇宙産業基盤の育成の 立場からも必要なものといえます。

$\mathrm{H}$ - II 開発の注目点は今までのように米国への 全面的依存の形でなく，今まで蓄績した技術を基 に自主性，自在性をもって挙国体制で行い，経済 性のあるものを実現するところにあります。さら ばと言って国産に固執するわけではなく，必要部 品は購入するなど貿易摩擦にも留意する必要があ リます。また独自に創造した技術は相互に尊重し， 各国と協調することが大切なことは言うまでもあ リません。

\section{5. スペースステーション}

$\mathrm{H}$ - II と並ぶ新しい大きい課題は米国からスペ ースステーション計画に参加するよう勧奨を受け ていることへの対応でありまして, 現在, 検討は 進んでいます。スペースステーションの利用目的 としては, 生命科学の研究, 無重力状態における 材料製造, 薬品合成, 衛星の修理や保守, 高度な 宇宙基地活動の諸準備, 燃料備蓄, などが挙げら れています。しかし今の段階ではその経済効果の 見極めはむずかしく，それよりも将来の宇宙活動 への基本的課題への挑戦と開拓に意義を見るべき ものでありましょう。欧州では米国の提案には強 い関心を示しております。とにかく独自の小型シ ヤトルの構想を描きながら, 米国のボストン・シ ヤトル計画は友好諸国の協力態勢の下に動き出そ うとしております。

\section{6. 衛星通信}

わが国は衛星通信の分野では電子工業の実績を 背景に1963年の日米間初のT V 衛星中継が行われ て以来，常に積極的な役割りを果して来ました。 とくにインテルサット（国際衛星通信機構）を通 じての貢献に見るものがあります。本年 6 月に来 日した事務局長コリーノ氏は日本が頭初，世界通 信のために静止衛星の採用を強調したことやまた その後の技術的貢献を評価しておりました。すな わち, 地球局技術としてK D Dで初めて実用化し た 4 枚反射器付きの大型アンテナ（現在の世界の 標準となっているもの) ディジタル T D M A 通信 方式の先駆的実験, また最近は静止衛星軌道の有
効利用プログラムの提案などは特に注目すべきも のであります。日本としてはこの分野で常に主導 的な貢献をして来たことをお伝えしておきます。

衛星通信はインテルサットの企業の下に固定衛 星業務の国際通信として大発展を遂げました。現 在ではインテルサットへの加入国数は 108 か国, 地球国の数は 1982 年末で 446 局にも達しました。 最近はさらに衛星通信の国内通信への利用が各国 で盛んになっております。日本でも通信衛星 CS一 2 により離島通信，さらに車戴局による災害通信， 臨時通信などの利用が始まりました。衛星通信は その特長として広い地域にわたって回線の設定保 守が容易なところから将来は小型の地球局による 世界的のビジネス通信への普及も期待されています。

衛星通信のもう一つの特長として移動通信への 応用がありますが，とくに海事移動衛星通信が急 速に普及しております。それはインマルサット (国際海事衛星機構) の下に運営されているもの であります。現在のインマルサットの加入国数は 40か国となりました。1984年 4 月末現在，世界の 船舵地球局の数は 2321 局 (内, 日本は 281 局, 占 有率は約 $12 \%$ )にも達し, 年率 35 40\%で増加 を続けています。

衛星通信はテレビ国際中継を含め世界を結ぶ手 段としてますますわれわれの身近かなものとなり つつあります。今後ともその健全な発展に寄与し たいものと考えます。

\section{【付 記】}

本稿は，北陸信越工業教育協会新潟県支部の新 潟大学工学部が, 長岡高等工業学校の創立の年か ら数えて 60 周年に当る本年, 新潟大学開学記念日 である 6 月 1 日に, 新潟市イタリア軒ホールで行 われた記念講演の記録である。 